UDC 711.522-024.526

\title{
PRACTICAL ASPECTS OF ESTABLISHING (CHANGING) THE BOUNDARIES OF ADMINISTRATIVE AND TERRITORIAL ENTITIES.
}

Dorosh O., Doctor of Economics, Professor

E-mail:dorosholgas@ukr.net

National University of Life and Environmental Sciences of Ukraine

Ibatullin S., Doctor of Economics, Professor, Corresponding Member of NAAS

E-mail: shamilibatullin@gmail.com

Tarnopolskyi Ye. Candidate of Technical Sciences (Ph.D)., assistant professor

E-mail: andrey0037@gmail.com

Kharytonenko R. Candidate of Economic Sciences (Ph.D.)

E-mail:kharytonenkor@gmail.com

Institute of Land Use of the National Academy of Agrarian Sciences of Ukraine

In order to establish (change) the boundaries of administrative-territorial entities using the example of Malaya Olshanka village, Belotserkovsky district, Kiev region, pre-project studies were conducted, namely: the materials of the master plan, the project of forming the boundaries of the village council and establishing its boundaries, the existing cartographic and topographical data were analyzed land cadastre, land-registration data. In addition, a reconnaissance survey was conducted on the territory of the village council in the zone of the existing and project boundary (defined by the master plan) of the specified rural settlement. It was established that a significant part of the project boundary according to the general plan divides land plots of landowners and land users, contours of land, contributes to the formation of enclaves in accordance with the law, in case of approval of such a limit will require the separation of such sites.

The need for a combination of urban planning documentation (master plan) with land management (land management project to establish (change) the boundaries of administrative-territorial entities) into a unified system of spatial (territorial) planning to create an effective tool in solving problems related to the formation and establishment of boundaries. 
Key words: project of land management, establishment of boundaries, change of boundaries, boundary of the settlement, administrative and territorial entity, master plan, spatial planning.

Formulation of the problem. It is well known that the basis for establishing and changing the boundaries of administrative-territorial units is urban planning and land management documentation. The master plan as a type of urban planning documentation provides for the solution of issues on planning and improvement of settlements for housing, transport communications, engineering networks, domestic and economic maintenance of the territories, as well as safe living for the population.

According to Article 173 of the Land Code of Ukraine, on land management, the task is to establish and change the boundaries of administrative-territorial units, taking into account the master plans of settlements [1]. Specifically, land management projects to establish (change) the boundaries of administrative and territorial entities is a type of land management documentation which provides for creating a full-fledged living environment and creating favorable conditions for their territorial development, ensuring effective use of the potential of territories while preserving their natural landscapes and historical and cultural values. interests of land owners, land users, including tenants, and approved town planning documentation [2].

The project of land management to establish (change) the boundaries of administrative and territorial entities is carried out with the aim of effectively managing the natural resource potential of territories, delimiting state and communal property lands.

When designing a new settlement boundaries, as provided for in the master plan, as a rule, there appears a discrepancy between the project boundary and the border projected taking into account the boundaries of land plots of landowners and land users, contours of land, existing restrictions 
(determining a certain mode of land use) that will later affect the legal the regime of the territory, the rational use of land resources and the sustainable development of territories in conditions of a possible conflict of interest

Analysis of recent research and publications. The question of establishing (changing) the boundaries of administrative-territorial entities, the research of domestic scientists was mainly directed to the development of methodological approaches to establish (change) the boundaries of settlements and to reveal theoretical aspects in this area of research. With the beginning of the reform of decentralization in Ukraine (the formation of united territorial communities), the introduction of territorial (spatial) planning, this problem requires new scientific research and its approbation in practice.

Research results and discussion. The object of the study is to establish (change) the boundaries with. Malaya Olshanka Malovilshansky village council of the Belotserkovsky district of the Kiev region. This settlement is the center of the Malovilshansky village council, which is located $16 \mathrm{~km}$ south of the district center of the city. Belaya Tserkov and $95 \mathrm{~km}$ from the regional center - the city of Kiev. In the nearest territorial neighbor from the north is the city. Belaya Tserkov, from the east with. Bykova Rowing and with. Cherkasy, from the south - with. Sorokotyag and with. Korzhovka and with. Bakaly in the west. Based on the village council data as of 01/01/2017, in the territory of s. Malaya Olshanka has a population of 1742 people. In accordance with the needs of the territorial community with. Malaya Olshanka (LLC PROEKTGENPLAN) developed a master plan providing for the organization of the territory for the development of the settlement and the accession of existing manufacturing enterprises. The first stage in the development of a land management project to establish (change) the boundary of an administrative-territorial unit was carried out preparatory work, including: scientific substantiation, collection, systematization and analysis of source data, translation of cartographic, planning materials and data into electronic form, the formation of possible options for the settlement, perform refining geodetic measurements. 
After analyzing the project of forming the boundaries of the village council and establishing the boundaries of the Malovilshansky village council, developed by the Kiev branch of the Institute of Land Management and land explication, it was found that the area of the Malovilshansky village council as of 01/01/1993 was 4,050.6 hectares, of which 516 are under the settlements, 2 ha. Area with Malaya Olshanka amounted to 346.5 hectares, and together with the area of the "working village" 388.3 hectares. According to the approved form of state statistical reporting of land resources (form No. 6-land), as of 01/01/2018, the existing land area within the settlements of Malovilshansky of the village council of the Belotserkovsky district of the Kiev region (Malaya Olshanka and Bakaly) is 516.5 ha Considering the materials of the state statistical reporting, the area of the village of Malaya Olshanka is 388.3 hectares.

An analysis of the master plan materials showed that almost $80 \%$ of the existing territory of the settlement is built up with residential, public buildings and transport infrastructure. According to the existing structure of land resources use, it can be stated that the opportunity for the development of a settlement within the existing limits is limited. Therefore, to ensure the development of the settlement, the general plan provides for additional territories. Planning organization of the territory Malaya Olshanka is designed to meet the needs of the development of the territorial community. Thus, according to the general plan, the territory with. Malaya Olshanka will increase by 606.0 ha and amount to 994.3 ha.

When conducting a reconnaissance survey of the existing and project boundary c. Malaya Olshanka, envisaged by the master plan, identified inconsistencies between the boundaries of the situation objects (road, forest, road network, boundaries of built-up areas, fences of economic yards, contours of relief elements) (mark in Figure 1 "1.5"). It was also found that the project boundary proposed by the master plan did not correspond to the areas registered in the State Land Cadastre, which are reflected in the public cadastral map of Ukraine (mark in Figure 1 "2.4").

In the north-eastern part of the settlement a border is proposed with. Mala Vlishanka goes beyond the Malovolshansk village council and is imposed on the 
territory of the Pylypchansky village council, which violates the existing system of local self-governance. Therefore, in the north-eastern part of the project the boundary of the settlement will be adjusted.

According to the master plan with. Malaya Olshanka included in the project borders a regional road with a length of more than 4 kilometers. In accordance with the Resolution of the Cabinet of Ministers of Ukraine dated January 30, 2019 No. 55 this public road belongs to the regional road R-17 (Belaya Tserkov - Tetiev - Lipovets - Humennoe), which is in the maintenance of the road service in the Kiev region [4].

Automobile roads, supposedly in the area between the locality, move to the streets and roads and the streets of the authorities of the local government and public authorities 16 of the Law of Ukraine "On Automobile Roads" [5]. On the basis of the organization of self-commissioning of the statute 19, the commitments of the organization, reconstruction, reconstruction, repair and repair are required. Фінансування будівництва, reconstructions, repairs and repairs that have been done for the population of the population points to the law of the state budget for the population of the settlements. Tobto at the included regional road P-17 in inter populated point s. Mala Vilshanka, separate to the general plan, the populations point Bude zobovyataniyu utrimuvati (remontvati) tsyu road (Fig. 1).

After analyzing the Public Cadastral Map of the State Land Cadastre, it was found that the project boundary between the working settlement and the village. Malaya Olshanka along the regional road P-17, a length of $1.9 \mathrm{~km}$, divides the borders of land plots of landowners and land users in accordance with the law will additionally require the separation of these sites. That is, the land management project is proposed not to include in the project limits of the settlement a regional road R-17, passing between the working settlements and the village. Malaya Malinovka. Thus, the settlement is two parts: exactly with. Malaya Olshanka with a project area of 767.4720 hectares and its working settlement with a project area of 214.9083 hectares, rather than combining them with a line along the regional highway R-17. 


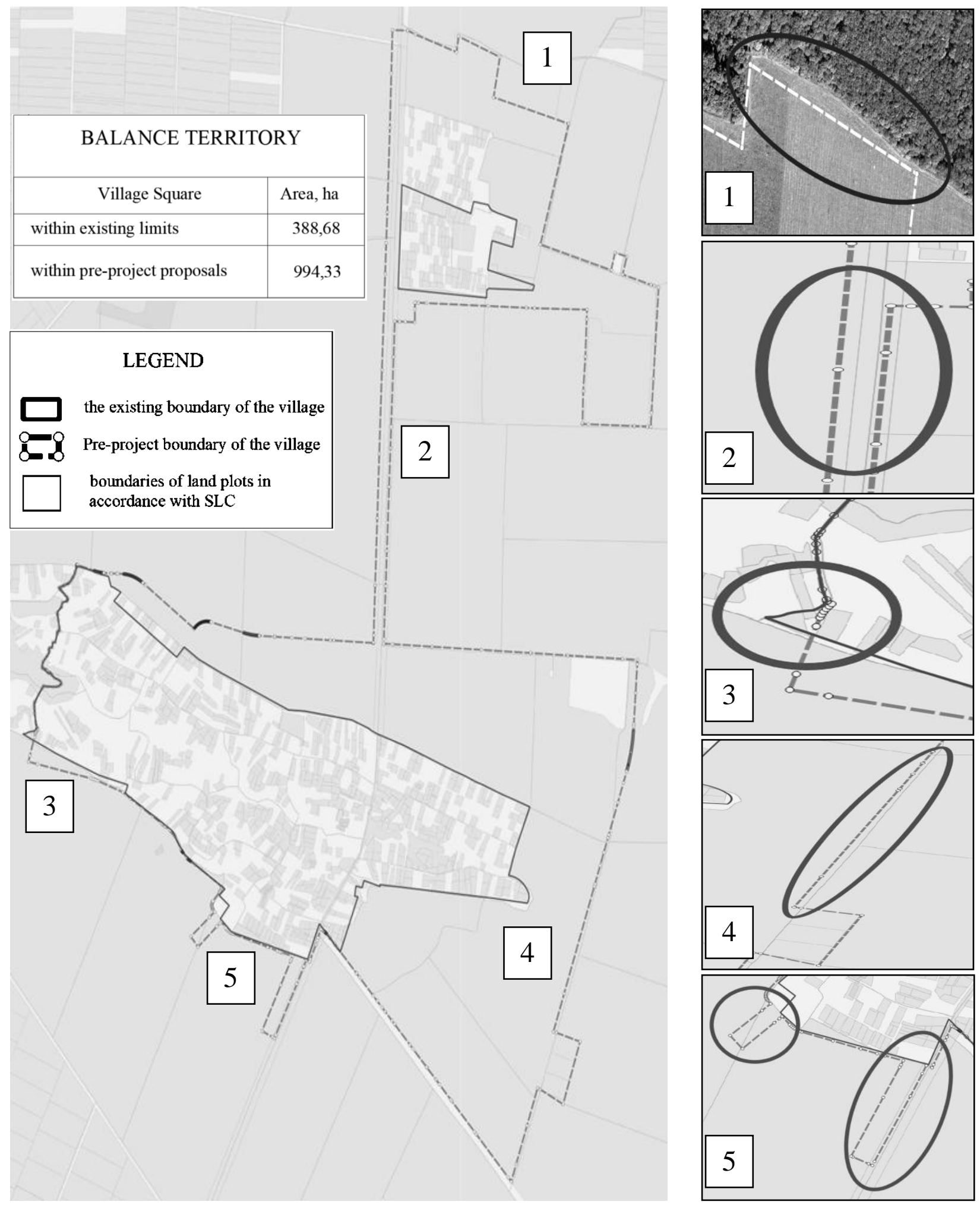

Fig. 1. Pre-project proposals for establishing (changing) the border of the village of Malaya Olshanka, Belotserkovsky district, Kiev region [8]

Changing the project boundary and reducing the project area in this area will not affect the project distribution of the territory and the design solutions proposed by the general plan of town planning documentation. 
In the southern part of the western border with. Malaya Olshanka general plan provides for the reduction of the territory of the village, where it borders on Bakaly. That is, land of 0.2912 ha will not be attached to the project boundaries of the settlement. In turn, these lands will not be attached to the village. Bakaly will not be developed a master plan for this locality (mark in Figure 1 "4").

It was also found that the area of the existing boundaries of the settlement did not coincide according to the explanatory note to the master plan, which amounted to 388.30 hectares and was calculated by the coordinates for the pre-project works provided by the master plan developer, which amounted to 388.6824 hectares of them: c. Malaya Olshanka, 349.5917 ha, "settlement worker", 39.0907 ha.

Thus, the project limit for the project of land management is updated to make up the area with. Malaya Olshanka, 982.3803 ha of 994.3 proposed by the master plan. The difference between the areas under the general plan and the project of land management is not the inclusion in the project limits of the regional road (R-17), which will not affect the overall project development of the settlement in accordance with the general plan.

The analysis of the project boundary proposed by the master plan for $\mathrm{p}$. Malaya Olshanka Malovilshansky village council of the Belotserkovsky district of the Kiev region revealed a number of problematic issues on the formation of the project boundary, namely:

- a significant part of the project limits of the settlement, which is proposed for the formation of divides formed borders of land plots of public and private property in accordance with the law can not be included in the borders of the village without their separation.

- in the northern part of the village within the project limits (in accordance with the master plan), if the boundary of the settlement is determined in accordance with the Master Plan, an enclave of arable land will be created, access and system processing of which will be impossible.

- in the southern part of the western border with. Malaya Olshanka general plan provides for the reduction of the territory of the village. 
- to the territory of the settlement, the general plan is designed to assign the State Highway (P-17).

- territory balance with. According to the explanatory note to the Master Plan and calculated by the coordinates provided by the master plan developer, Malaya Olshanka in the project limits does not coincide.

The specified limit by the land management project to respond to the efficient use of land resources, to influence the project decisions of the development of the settlement planned by the master plan (Table 1, Fig. 2).

1. Change of boundaries and area of the settlement according to the general plan and the project of land management to establish (change) borders with. Malaya Olshanka Belotserkovsky district of Kiev region

\begin{tabular}{|c|c|c|c|c|}
\hline \multicolumn{5}{|c|}{ The area of the settlement within the existing limits } \\
\hline \multicolumn{3}{|c|}{ According to the master plan } & \multicolumn{2}{|c|}{ Under the project of land management } \\
\hline \multicolumn{2}{|c|}{388,30 hectares } & \multicolumn{3}{|c|}{$\begin{array}{c}\text { 388,6824 hectares, } \\
\text { of them: with. Mala Vilshanka, 349.5917 } \\
\text { hectares, working settlement, 39,0907 hectares }\end{array}$} \\
\hline \multicolumn{5}{|c|}{ Project proposals for changing the area of the settlement } \\
\hline $\begin{array}{l}\text { The lands that } \\
\text { will be included } \\
\text { in the boundaries } \\
\text { of the settlement } \\
\text { in accordance } \\
\text { with the master } \\
\text { plan, hectares }\end{array}$ & $\begin{array}{l}\text { Area of the } \\
\text { settlement within } \\
\text { the project } \\
\text { boundaries in } \\
\text { accordance with } \\
\text { the general plan, } \\
\text { hectares }\end{array}$ & $\begin{array}{c}\text { Land that will } \\
\text { not be included } \\
\text { in the } \\
\text { boundaries of } \\
\text { the settlement, } \\
\text { hectares }\end{array}$ & $\begin{array}{l}\text { The lands that } \\
\text { will be included } \\
\text { in the boundaries } \\
\text { of the settlement } \\
\text { in accordance } \\
\text { with the land } \\
\text { management } \\
\text { project, hectares }\end{array}$ & $\begin{array}{c}\text { Area of the } \\
\text { settlement } \\
\text { within the } \\
\text { project } \\
\text { boundaries in } \\
\text { accordance } \\
\text { with the project } \\
\text { of land } \\
\text { management, } \\
\text { hectares }\end{array}$ \\
\hline 606,0 & 994,3 & 0,2912 & 593,9891 & 982,3803 \\
\hline
\end{tabular}


Project limit under the master plan

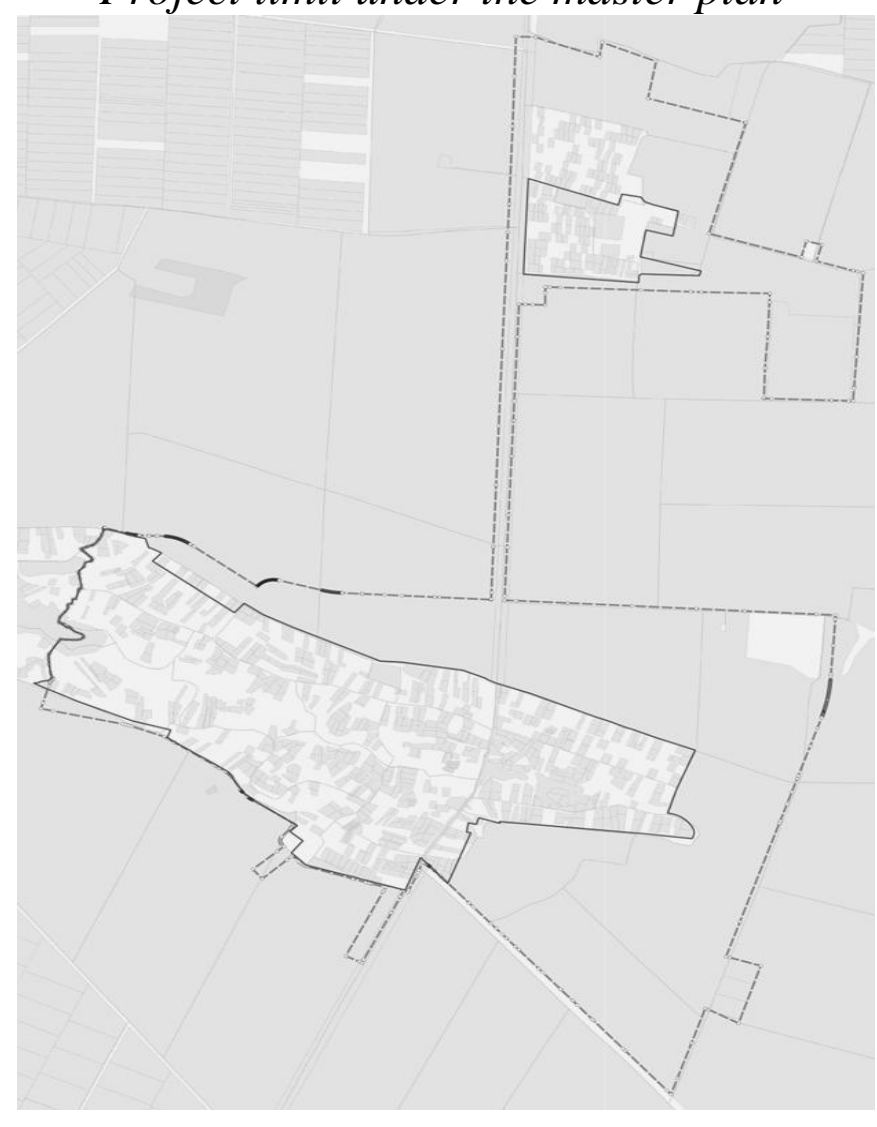

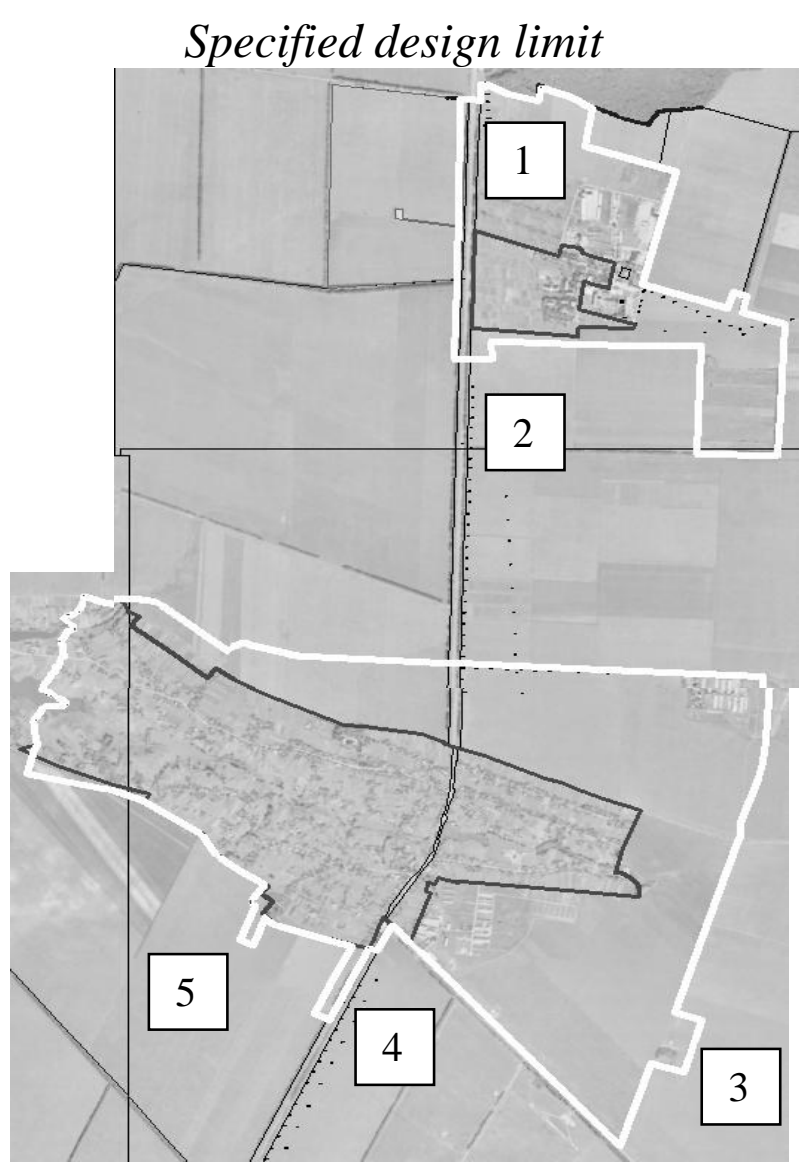
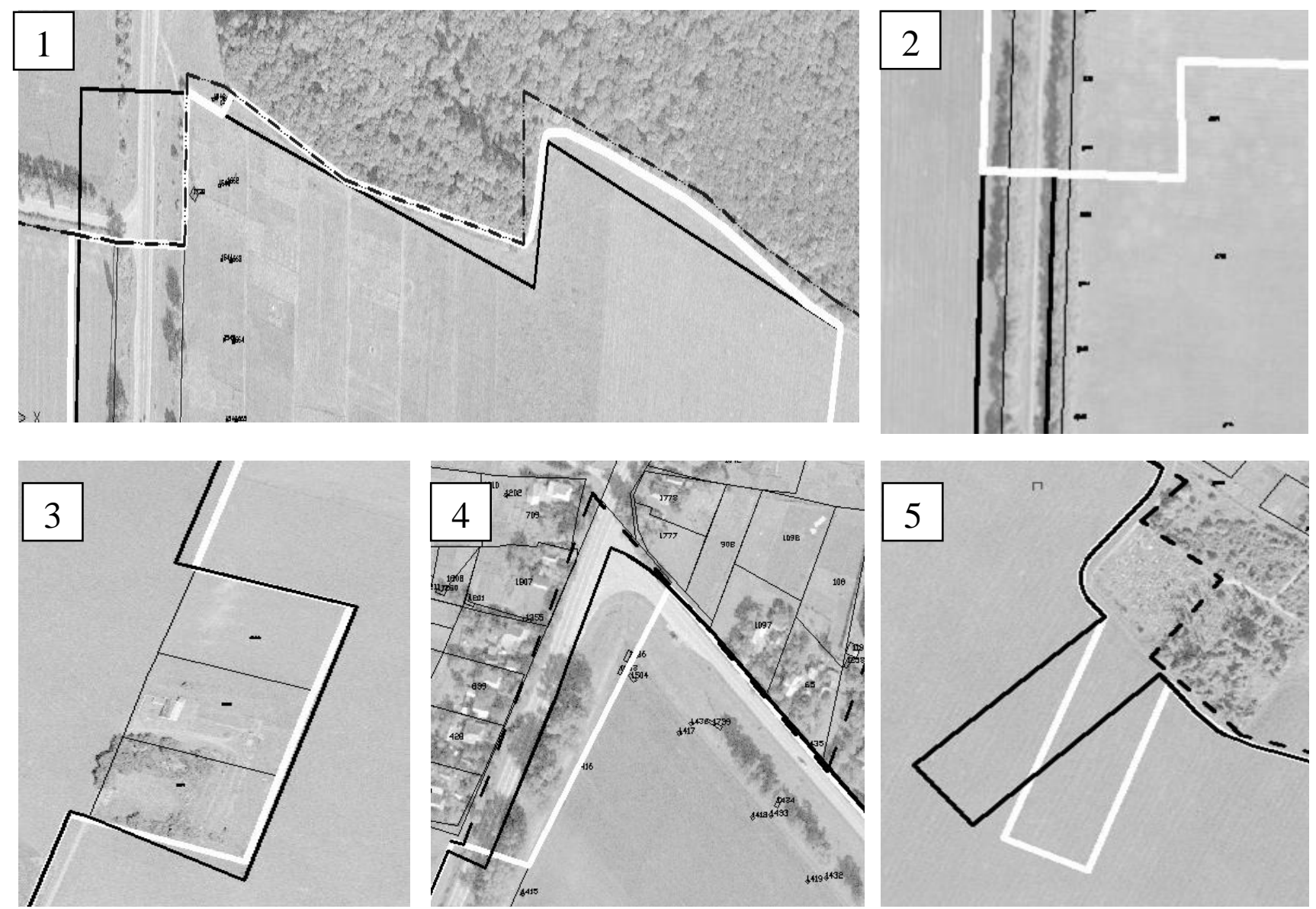

Fig. 2. Updated new (project) limit of the village of Malaya Olshanka, Belotserkovsky district, Kiev region [8] 
Conclusions and perspectives. In order to create a full-fledged living environment and favorable conditions for the territorial development of a settlement, a master plan is developed and, on its basis, a land management project to establish (change) the boundaries of administrative-territorial entities.

The development and implementation of a master plan for villages, towns and small cities is a costly, time-consuming and not expedient process that can drag on for years, and the implementation of its capabilities within small localities is impossible with a constant decrease in population. The master plan, as a comprehensive urban planning document, needs to be developed only for settlements, being built from scratch or substantially enhancing the existing infrastructure, as is the case in large cities.

For small settlements, it is necessary to change the approach of developing urban planning documentation for the future of their development of the territory and move on to the planning of large areas as spatial (territorial) planning. This type of work has shown its effectiveness and efficiency in Western countries.

Summing up, we note that to create favorable conditions for the territorial development of human settlements there is a need to combine urban planning documentation (master plan) with land management (land management project to establish (change) the boundaries of administrative and territorial entities) into a single system of spatial (territorial) planning, and to eliminate inconsistencies between these processes. The proposed approach will be an effective tool in solving problems associated with the formation and establishment of boundaries of united territorial communities.

\section{References}

1. Zemelnyi kodeks Ukrainy. Hlava 29 «Vstanovlennia ta zmina mezh administratyvno-terytorialnykh odynyts».

URL: https://zakon.rada.gov.ua/laws/show/2768-14

2. Zakon Ukrainy «Pro zemleustrii». Stattia 46 «Proekty zemleustroiu shchodo vstanovlennia (zminy) mezh administratyvno-terytorialnykh utvoren. URL: https://zakon.rada.gov.ua/laws/show/858-15 
3. Publichna kadastrova karta Ukrainy. Derzhavnyi zemelnyi kadastr URL: http://map.land.gov.ua/kadastrova-karta

4. Kabinet Ministriv Ukrainy Postanova «Pro zatverdzhennia pereliku avtomobilnykh dorih zahalnoho korystuvannia derzhavnoho znachennia» URL: https://zakon.rada.gov.ua/laws/show/55-2019-\%D0\%BF

5. Zakon Ukrainy «Pro avtomobilni dorohy» URL: https://zakon.rada.gov.ua/laws/show/2862-15

Дорош О.С., Ібатуллін Ш.І., Тарнопольський С.А., Харитоненко Р.А. ПРАКТИЧНІ АСПЕКТИ ВСТАНОВЛЕННЯ (ЗМІНИ) МЕЖ АДМІНІСТРАТИВНО-ТЕРИТОРІАЛЬНИХ УТВОРЕНЬ

3 метою встановлення (зміни) меж адміністративно-територіальних утворень на прикладі села Мала Вільшанка Білоцерківського району Київської області проведено передпроектні дослідження, а саме: проаналізовано матеріали генерального плану, проект формування меж сільської ради та встановлення ї̈ меж, наявну картографічну і топографічну основи, дані державного земельного кадастру, земельно-облікові дані. Крім того було проведено рекогносиироване обстеження території сільської ради в зоні існуючої та проектної межі (визначеної генеральним планом) зазначеного сільського населеного пункту. Встановлено, що значна частина проектної межі за генеральним планом ділить сформовані земельні ділянки землевласників і землекористувачів, контури угідь, сприяє утворенню анклавів $i$ відповідно до законодавства, у разі затвердження такої межі буде вимагати поділу таких ділянок.

Обгрунтовано потребу в поєднанні містобудівної документації (генерального плану) із землевпорядною (проекту землеустрою щэодо встановлення (зміни) меж адміністративно-територіальних утворень) в єдину систему просторового (територіального) планування для створення ефективного інструменту у розв'язанні проблем пов'язаних із формуванням та встановленням меж. 
Ключові слова: проект землеустрою, встановлення меж, зміна меж, межа населеного пункту, адміністративно-територіальне утворення, генеральний план, просторове планування.

Дорош О.С., Ибатуллин Ш.И., Тарнопольский Е.А., Харитоненко Р.А. ПРАКТИЧЕСКИЕ АСПЕКТЫ УСТАНОВЛЕНИИ (ИЗМЕНЕНИИ) ГРАНИЦ АДМИНИСТРАТИВНО-ТЕРРИТОРИАЛЬНЫХ

\section{ОБРАЗОВАНИЙ}

С цуелью установления (изменения) границ̧ административнотерриториальных образований на примере села Малая Ольшанка Белоцерковского района Киевской области проведено предпроектные исследования, а именно: проанализированы материаль генерального плана, проект формирования границ сельского совета и установления его границ, имеюшуюся картографическую и топографическую основы, данные государственного земельного кадастра, земельно-учетные данные. Кроме того, было проведено рекогносцироване обследования территории сельского совета в зоне сущуествующей и проектной гранищь (определенной генеральньм планом) указанного сельского населенного пункта. Установлено, что значительная часть проектной границьы по генеральному плану делит сформированы земельные участки землевладельц̧ев и землепользователей, контуры угодий, способствует образованию анклавов в соответствии с законодательством, в случае утверждения такого предела будет требовать разделения таких участков.

Обоснованно потребность в сочетании градостроительной документаџии (генерального плана) с землеустроительной (проекта землеустройства по установлению (изменения) границ административнотерриториальных образований) в единую систему пространственного (территориального) планирования для создания эффективного инструмента в решении проблем, связанных с формированием и установлением границ. 
Ключевые слова: проект землеустройства, установление границ, изменение границ, граница населенного пункта, административнотерриториальное образование, генеральный план, пространственное планирование. 